\title{
Motherhood and HIV: reproductive desire, ambivalent feelings and a/an (not) offered care
}

\author{
Maternidade e HIV: desejo reprodutivo, sentimentos ambivalentes e cuidado (não) ofertado \\ Maternidad y VIH: deseo reproductivo, sentimientos ambivalentes y cuidado (no) oferecido
}

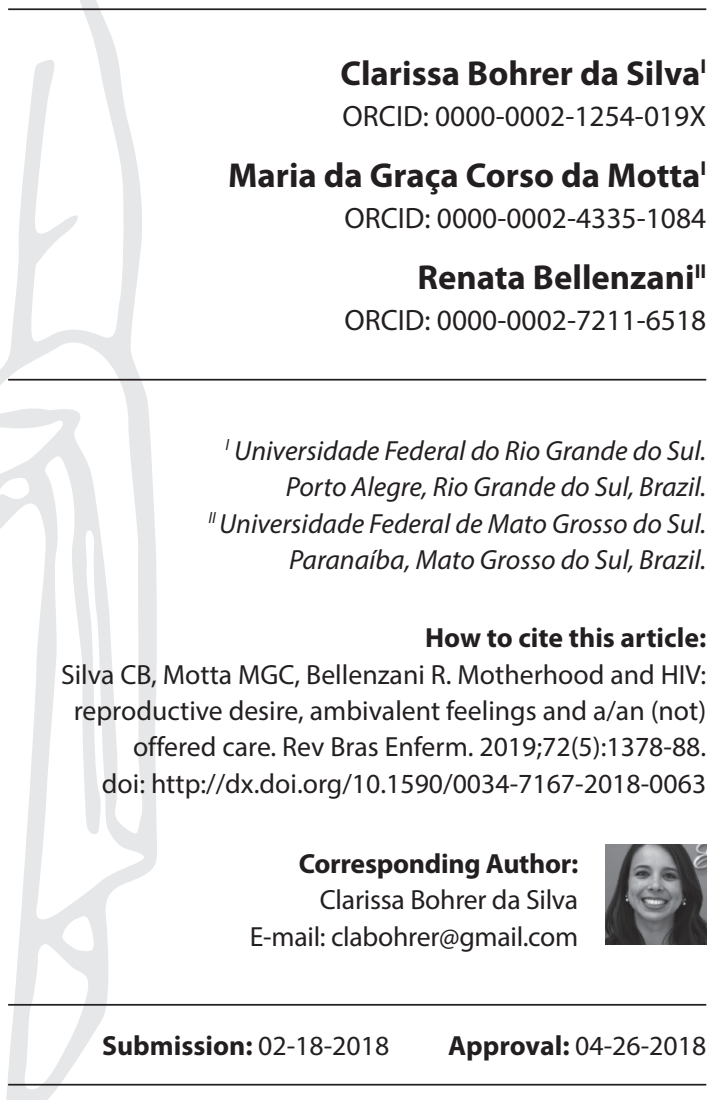

\begin{abstract}
Objective: To identify in the scientific literature the feelings of women living with HIV in relation to reproduction and motherhood, as well as the care provided by health professionals regarding reproductive health as a right. Method: Integrative review carried out in 2017, in the databases LILACS, PUBMED, BDENF and SciELO Virtual Library. We analyzed 30 articles. Results: As feelings, the motivation for reproduction and self-care, fears, uncertainties and hopes were evidenced. As care, services that support reproductive decisions were evidenced, but, predominantly, the disregard for the desire and care incipience for reproductive planning. Conclusion: There is no comprehensive and humanized work on the reproductive issues of these women, either through the neglect of the desire and viability of gestation or by the incipient care to the ambivalent emotional experiences. There is a need to qualify the care model in order to configure it, in fact, as care, aiming at guaranteeing reproductive rights. Descriptors: HIV; Acquired Immunodeficiency Syndrome; Pregnancy; Sexual and Reproductive Rights; Women's Health.
\end{abstract}

\section{RESUMO}

Objetivo: Identificar na literatura científica os sentimentos de mulheres que vivem com HIV em relação à reprodução e à maternidade, bem como os cuidados disponibilizados pelos profissionais de saúde no que tange à saúde reprodutiva como direito. Método: Revisão integrativa realizada em 2017, nas bases de dados LILACS, PUBMED, BDENF e Biblioteca Virtual SciELO. Foram analisados 30 artigos. Resultados: Como sentimentos, evidenciaram-se a motivação para a reprodução e autocuidado, medos, incertezas e esperanças. Como cuidados, evidenciaram-se serviços que oferecem apoio às decisões reprodutivas, mas, predominantemente, o descaso quanto ao desejo e à incipiência assistencial para planejamento reprodutivo. Conclusão: Não há um trabalho integral e humanizado quanto às questões reprodutivas dessas mulheres, seja pela negligência ao desejo e à viabilização da gestação ou pela atenção incipiente às vivências emocionais ambivalentes. Há necessidade de qualificação do modelo assistencial de modo a configurá-lo, de fato, como cuidado, visando a garantia dos direitos reprodutivos.

Descritores: HIV; Síndrome da Imunodeficiência Adquirida; Gravidez; Direitos Sexuais e Reprodutivos; Saúde da Mulher.

\section{RESUMEN}

Objetivo: Identificar en la literatura científica los sentimientos de mujeres que viven con $\mathrm{VIH}$ en relación a la reproducción y la maternidad, así como los cuidados ofrecidos por los profesionales de salud en lo que se refiere a la salud reproductiva como derecho. Método: Revisión integrativa realizada en 2017, en las bases de datos LILACS, PUBMED, BDENF y Biblioteca Virtual SciELO. Se analizaron 30 artículos. Resultados: Como sentimientos, se evidenció la motivación para la reproducción y autocuidado, miedos, incertidumbres y esperanzas. Como cuidados, se evidenciaron servicios que brindan apoyo a las decisiones reproductivas, pero, predominantemente, el descuido en cuanto al deseo ya la incipiente asistencial para planificación reproductiva. Conclusión: No hay un trabajo integral y humanizado en cuanto a las cuestiones reproductivas de esas mujeres, sea por la negligencia al deseo y la viabilidad de la gestación o por la atención incipiente a las vivencias emocionales ambivalentes. Hay necesidad de calificación del modelo asistencial para configurarlo, de hecho, como cuidado, buscando la garantía de los derechos reproductivos. Descriptores: VIH; Síndrome de Inmunodeficiencia Adquirida; Embarazo; Derechos Sexuales y Reproductivos; Salud de la Mujer. 


\section{INTRODUCTION}

In Brazil, from 1980 to June 2015, of the total of 798,366 cases of AIDS reported, 278,960 (35\%) correspond to women diagnosed ${ }^{(1)}$. The concentration of cases in the age groups of fertile age, mainly from 15 to 39 years, occurs because sexual intercourse represents the main form of HIV transmission(1). The male/female condom, regardless of the seropositivity of the partner, is a resource that serves the different protection functions: in relation to an unplanned pregnancy, Sexually Transmitted Infections and also HIV reinfection ${ }^{(2)}$.

In the context of HIV, it is possible to assume that technological and clinical advances allow a better coexistence with this chronic disease and the lower risk of sexual transmission, when viral suppression is reached as a clinical outcome of a good adherence to treatment. This tends to favorably affect the exercise of sexuality and reproduction in the broadening of the perspective of the future and in personal investment in guiding projects of daily life ${ }^{(3)}$. At the beginning of the epidemic, infected women were discouraged from getting pregnant and were heavily censored by the health team, resulting in miscarriages or treatment discontinuation ${ }^{(4)}$.

The rights to health of women with HIV and the unborn imply in the State's obligation, operated by health policies and services, to ensure that motherhood does not pose risks to its health and to others involved, either through Vertical Transmission (VT), or between seronegative or seropositive partners ${ }^{(5)}$. The possibility of prevention of HIV VT, with the prophylaxis strategies recommended by the Ministry of Health ${ }^{(6)}$ (Antiretroviral Therapy in prenatal, in childbirth and for the exposed newborn, indication of cesarean delivery, and replacement of breastfeeding by milk formulas), has resulted in progress regarding the reproductive decisions of this population.

Pregnancy, in the context of HIV, consists of a reproductive right to be respected and, therefore, a challenge for the field of Health, both in order to guarantee the appropriate conditions as well as to carry out theoretical-practical research on the subject. However, the impact of the values and attitudes of health professionals on social norms and stereotypes about the epidemic results in a point of tension with implications both for the prevention of infection and for the free exercise of reproductive rights. Specialized HIV services still fail to provide psychosocial care and overcoming ${ }^{(5)}$. Although they responded with an emphasis on VT prevention, they are not guided by the principle of integrality, which would presuppose consideration of women as a social being and subject of rights (besides a body under medical care). It is thus corroborated with an organicist welfare model and historically marked by the benefit to the child to the detriment of the woman, illustrated by the permanence of the focus of public policies ${ }^{(5,7)}$.

Currently, there are technical possibilities available in health services for HIV-positive women who wish to become pregnant. In addition to the effectiveness of ARVT to reduce viral load, assisted reproductive offer is an option for seropositive or serodifferent couples $^{(4)}$, although not fully available by the Brazilian Unified Health System (SUS - Sistema Único de Saúde).

Understanding the phenomenon of motherhood in seropositive women, from experiences related to reproductive desire, to the preparation phase for conception and to the verification of ongoing and postpartum gestation, is fundamental for a clearer analysis of a framework that, in the plan of public policies, is still approached in an organic, simplistic and homogenizing way ${ }^{(5)}$.

\section{OBJECTIVE}

To identify in the scientific literature the feelings of women living with HIV related to reproduction and motherhood, as well as the care provided by health professionals regarding reproductive health as a right.

\section{METHOD}

It is an integrative review that brings together the results of primary research on the same subject in order to develop a broader explanation of a phenomenon. The integrative review is developed in five stages: problem formulation, data collection, data evaluation, analysis and interpretation of data collected and presentation of results ${ }^{(8)}$.

The formulation of the problem is characterized by the question of research: what are the feelings of women living with HIV in relation to the possibilities of reproduction and motherhood, and what care is available or not by health professionals in this process?

The search for data collection was performed in March 2017, in the databases LILACS, PUBMED and BDENF and the SciELO Virtual Library. Such search sites were selected because they were renowned and widely consulted due to their contribution to the area of Health.

The search was performed by crossing the terms of the database Descriptors in Health Sciences: "HIV" OR "AIDS" [Subject descriptor] AND "pregnancy" [Subject descriptor] AND "care" [Words]. In order to increase the number of articles responding to the research question, another search was performed in each database, using the descriptors: "HIV" OR "AIDS" and "reproductive rights" [Subject descriptor]. In the PUBMED database, the respective terms were used in the Medical Subject Heading (MeSH).

The inclusion criteria in the study were: original articles; in Portuguese, English or Spanish; available online for free and in full. The articles without abstract in the database were excluded and did not respond to the objective of the study.

The evaluation of the data occurred through the reading of the titles and abstracts, which were submitted to the mentioned criteria. Figure 1 presents the process of selection of scientific articles.

For the analysis and interpretation of its contents, a complete reading of the selected articles was done and a documentary extraction form was created that includes: article identification, origin (data collection location), area of knowledge, year of publication, objective and design of the study (adopting concepts used by the authors themselves), level of evidence, main results, conclusions and recommendations of the authors. Evaluation by level of evidence was performed according to the seven levels described by Melnyk and Fineout-Overholt ${ }^{(9)}$.

In the present study, the notion of Care is used to refer to a way of producing health that is distinguished by the valorization of the dialogical and relational dimension between health professionals and users, allowing a broad understanding and negotiation around the constructions of health projects articulated to the social needs and projects of happiness of the people. Strongly supported by the perspective of completeness, it seeks to overcome a care model based on scientific-technological rationality, pursuing "technical success", 

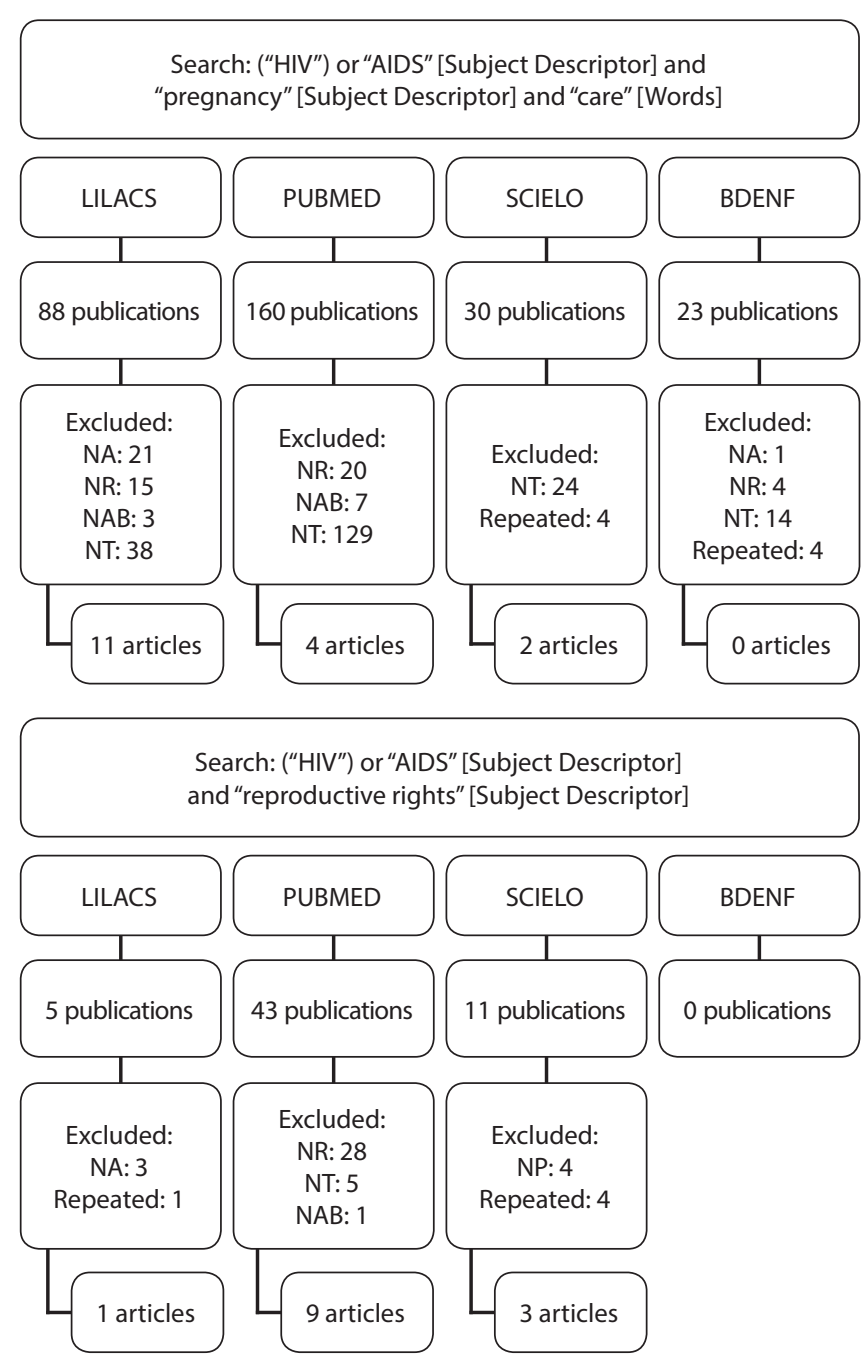

Note - NR - Not a Research; NT - Not from the Theme; NAB - No Abstract; NA - Not an Article.

Figure 1 - Process of selection of scientific articles in LILACS, PUBMED, BDENF and SciELO databases, 2017 in the form of "products" of health work as good clinical outcomes of treatments, insofar as simultaneously express themselves as "practical successes". These, in turn, express the personal senses and values of the user that base their demands that concretely produce a greater personal mobilization to care for oneself and justify the caregiver encounter ${ }^{(10)}$. As an inseparable component of Care ${ }^{(10)}$, there is the notion of psychosocial care ${ }^{(11-12)}$ that refers to the intersubjective dimension of social experiences of illness and health production, in order to integrate actions of a technical nature, such as clinical guidelines, with attention and appreciation of the intersubjective reality in which the lives (and therefore the sickness and the search for health) develop. The center of the dialogue is the daily life of the person, which encompasses his experiences of treatment, but is not restricted to these. The focus of attention on the body is expanded, for the person, immersed in culture and integrated into the reference groups; hence the 'psychosocial' attribute of attention ${ }^{(12)}$.

In addition, it should be noted that the term "feelings" is being used, in the present study, not feeling more usual and generic, without a theoretical affiliation to some specific current of psychology, but seeking studies that consider the dimension of subjectivity, being a concept of a broader and more polysemic nature, encompasses a set of categories, among them, feelings. It was chosen for its use in the attempt of greater precision and clarity, which would be more difficult with the use of terms such as subjective aspects, emotional aspects or subjectivity. It is worth noting that the analyzed works do not use the concept of feelings directly and those who use it do not necessarily do so in order to make explicit their affiliation to some psychological school.

The analysis was performed in a descriptive way and was presented in a general synoptic chart (Chart 1). The presentation of the results will be through figures, tables and charts that will show the synthesis and comparison of the authors' ideas about the proposed theme. Regarding ethical aspects, the authors'ideas and definitions were respected, maintaining their authenticity, ensuring authorship and citation in accordance with the norms of citations and Law 9,610 for copyright.

Chart 1 - Synoptic chart of articles analyzed, LILACS, PUBMED, BDENF e SciELO, 2017

\begin{tabular}{|c|c|c|}
\hline $\begin{array}{l}\text { Article/Year/ } \\
\text { Country }\end{array}$ & Objective & Outlining/ Population \\
\hline $\begin{array}{l}\text { Article } 1^{(13)} \\
2015, \text { Brazil }\end{array}$ & $\begin{array}{l}\text { To identify the perception of pregnant women living with HIV about motherhood } \\
\text { and to know the expectations and feelings experienced by these women }\end{array}$ & $\begin{array}{l}\text { Qualitative study. } \\
\mathrm{P}=10 \text { pregnant women with HIV }\end{array}$ \\
\hline $\begin{array}{l}\text { Article } 2^{(14)} \\
2012 \text {, South Africa }\end{array}$ & $\begin{array}{l}\text { To explore contraceptive decision-making among antenatal clinic participants } \\
\text { in South Africa, fertility intent after HIV diagnosis, and women's experiences in } \\
\text { government health services }\end{array}$ & $\begin{array}{l}\text { Qualitative study. } \\
\mathrm{P}=18 \text { women, being } 10 \\
\text { seronegative and } 8 \text { seropositive }\end{array}$ \\
\hline $\begin{array}{l}\text { Article } 3^{(15)} \\
2002, \text { Brazil }\end{array}$ & $\begin{array}{l}\text { To study issues related to sexuality and reproductive health of HIV positive women, } \\
\text { their access to prevention practices, their adherence to treatments and the possibility } \\
\text { to make conscious choices regarding pregnancy. }\end{array}$ & $\begin{array}{l}\text { Quantitative study. } \\
\mathrm{P}=148 \text { women with HIV }\end{array}$ \\
\hline $\begin{array}{l}\text { Article } 4^{(16)} \\
2009, \text { Brazil }\end{array}$ & $\begin{array}{l}\text { To investigate the perception of women with HIV/AIDS regarding the effects of } \\
\text { seropositivity on their reproductive choices. }\end{array}$ & $\begin{array}{l}\text { Qualitative study. } \\
\mathrm{P}=30 \text { women with HIV }\end{array}$ \\
\hline $\begin{array}{l}\text { Article } 5^{(17)} \\
2007, \text { Brazil }\end{array}$ & $\begin{array}{l}\text { To describe attitudes toward parenthood and identify factors associated with the } \\
\text { desire to have children among men and women living with HIV }\end{array}$ & $\begin{array}{l}\text { Quantitative, cross-sectional study. } \\
P=533 \text { women and } 206 \text { men }\end{array}$ \\
\hline $\begin{array}{l}\text { Article } 6^{(18)} \\
\text { 2007, Brazil }\end{array}$ & $\begin{array}{l}\text { To investigate the non-adherence of pregnant women carriers of HIV/AIDS to the } \\
\text { treatment recommended by the Ministry of Health in the prenatal period. }\end{array}$ & $\begin{array}{l}\text { Qualitative study. } \\
\mathrm{P}=7 \text { women not adherent to } \\
\text { prophylaxis during pregnancy }\end{array}$ \\
\hline $\begin{array}{l}\text { Article } 7^{(19)} \\
2015, \text { Brazil }\end{array}$ & $\begin{array}{l}\text { To describe the desire to be a mother with HIV and identify her feelings and } \\
\text { perceptions regarding this issue }\end{array}$ & $\begin{array}{l}\text { Qualitative study. } \\
P=1 \text { patient with HIV }\end{array}$ \\
\hline
\end{tabular}


Chart 1 (concluded)

\begin{tabular}{|c|c|c|}
\hline $\begin{array}{l}\text { Article/Year/ } \\
\text { Country }\end{array}$ & Objective & Outlining/ Population \\
\hline $\begin{array}{l}\text { Article } 8^{(20)} \\
2013, \text { Brazil }\end{array}$ & $\begin{array}{l}\text { To analyze the perception of HIV-positive women about the decision to become } \\
\text { pregnant; Investigate knowledge about HIV care in the prevention of Vertical } \\
\text { Transmission. }\end{array}$ & $\begin{array}{l}\text { Qualitative study. } \\
\mathrm{P}=8 \text { women HIV }\end{array}$ \\
\hline $\begin{array}{l}\text { Article } 9^{(21)} \\
\text { 2006, Brazil }\end{array}$ & $\begin{array}{l}\text { To understand how the risk of HIV transmission is apprehended and reconstructed by } \\
\text { people living with HIV/AIDS in their reproductive decisions. }\end{array}$ & $\begin{array}{l}\text { Qualitative study. } \\
\mathrm{P}=8 \text { women and men }\end{array}$ \\
\hline $\begin{array}{l}\text { Article } 10^{(22)} \\
2008, \text { South Africa }\end{array}$ & $\begin{array}{l}\text { To investigate the perceptions and experiences of women and men on the care and } \\
\text { treatment of HIV/AIDS and sexual and reproductive health care. }\end{array}$ & $\begin{array}{l}\text { Qualitative study. } \\
\mathrm{P}=35 \text { women an } 27 \text { men }\end{array}$ \\
\hline $\begin{array}{l}\text { Article } 11^{(23)} \\
2015, \text { Brazil }\end{array}$ & To unveil the meaning of HIV Vertical Transmission prophylaxis for the couple. & $\begin{array}{l}\text { Qualitative study. } \\
P=7 \text { couples }\end{array}$ \\
\hline $\begin{array}{l}\text { Article } 12^{(24)} \\
2014 \text {, Tailândia }\end{array}$ & $\begin{array}{l}\text { To explore the experiences of pregnancy and birth, motherhood and infant feeding } \\
\text { practices among women living with HIV/AIDS in Thailand. }\end{array}$ & $\begin{array}{l}\text { Qualitative study. } \\
\mathrm{P}=26 \text { people with HIV }\end{array}$ \\
\hline $\begin{array}{l}\text { Article } 13^{(25)} \\
2014, \text { México }\end{array}$ & $\begin{array}{l}\text { To explore the experiences of HIV-infected women who have sought health care for a } \\
\text { current or recent pregnancy. }\end{array}$ & $\begin{array}{l}\text { Qualitative study. } \\
\mathrm{P}=31 \text { women with HIV }\end{array}$ \\
\hline $\begin{array}{l}\text { Article } 14^{(26)} \\
\text { 2015, Brazil }\end{array}$ & $\begin{array}{l}\text { To know how women living with HIV/AIDS attach meaning to their reproductive } \\
\text { decisions, as well as characterize their unconscious desire. }\end{array}$ & $\begin{array}{l}\text { Qualitative study. } \\
\mathrm{P}=15 \text { women com HIV }\end{array}$ \\
\hline $\begin{array}{l}\text { Article } 15^{(27)} \\
2006, \text { Brazil }\end{array}$ & $\begin{array}{l}\text { To analyze when and how gender representations and ideologies permeate and } \\
\text { structure professional/patient relationships around AIDS treatment. }\end{array}$ & $\begin{array}{l}\text { Qualitative study. } \\
\mathrm{P}=7 \text { professionals and } 10 \text { HIV- } \\
\text { positive women }\end{array}$ \\
\hline $\begin{array}{l}\text { Article } 16^{(28)} \\
2014, \text { Brazil }\end{array}$ & $\begin{array}{l}\text { To analyze the experience of family members in the care of the mother child with HIV } \\
\text { to reduce the risk of VT, with emphasis on the beginning of this trajectory. }\end{array}$ & $\begin{array}{l}\text { Qualitative study. } \\
\mathrm{P}=36 \text { family members of children } \\
\text { exposed to HIV }\end{array}$ \\
\hline $\begin{array}{l}\text { Article } 17^{(29)} \\
2010, \text { Brazil }\end{array}$ & To verify non-verbal communication between mother and child during maternal HIV. & $\begin{array}{l}\text { Experimental research. } \\
\mathrm{P}=5 \text { mothers with HIV }\end{array}$ \\
\hline $\begin{array}{l}\text { Article } 18^{(30)} \\
2006, \text { Brazil }\end{array}$ & To apprehend the feelings experienced by pregnant women with HIV. & $\begin{array}{l}\text { Qualitative study. } \\
\mathrm{P}=9 \text { pregnant women }\end{array}$ \\
\hline $\begin{array}{l}\text { Article } 19(31) \\
2011, \text { Brazil }\end{array}$ & $\begin{array}{l}\text { To understand how HIV positive teens deal with their sexual experiences and dating } \\
\text { projects, desire to start a family and to have children. }\end{array}$ & $\begin{array}{l}\text { Qualitative study. } \\
\mathrm{P}=21 \text { HIV teenagers and } 13 \\
\text { caregivers }\end{array}$ \\
\hline $\begin{array}{l}\text { Article } 20^{(32)} \\
2012, \text { Malawi }\end{array}$ & $\begin{array}{l}\text { To evaluate the use of reproductive health care and incidence of pediatric infection } \\
\text { during the expansion of Antiretroviral Therapy and services for the prevention of } \\
\text { vertical transmission in rural areas of Malawi. }\end{array}$ & $\begin{array}{l}\text { Descriptive quantitative study } \\
\text { through review of records and } \\
\text { databases. }\end{array}$ \\
\hline $\begin{array}{l}\text { Article } 21^{(33)} \\
2012, \text { United } \\
\text { Kingdom and } \\
\text { Ireland }\end{array}$ & $\begin{array}{l}\text { To explore the pattern of pregnancy replication among HIV-infected women, } \\
\text { estimate the rate of these sequential pregnancies, and investigate the demographics } \\
\text { and clinics of the women who experience them. }\end{array}$ & $\begin{array}{l}\text { Quantitative study. } \\
\mathrm{P}=14,096 \text { pregnancies in } 10,568 \\
\text { women }\end{array}$ \\
\hline $\begin{array}{l}\text { Article } 22^{(34)} \\
2009, \text { Argentina }\end{array}$ & $\begin{array}{l}\text { To explore the experiences and contraceptive and reproductive needs of people } \\
\text { living with HIV and the responses of public health services to them in Argentina. }\end{array}$ & $\begin{array}{l}\text { Qualitative study. } \\
\mathrm{P}=841 \text { people with HIV and } 89 \\
\text { coordinators and professionals from } \\
\text { HIV programs }\end{array}$ \\
\hline $\begin{array}{l}\text { Article } 23^{(35)} \\
2014, \text { Brazil }\end{array}$ & $\begin{array}{l}\text { To identify coping strategies of } 77 \text { pregnant HIV-positive women enrolled in a public } \\
\text { health service. }\end{array}$ & $\begin{array}{l}\text { Quantitative, cross-sectional study. } \\
\mathrm{P}=77 \text { HIV-positive pregnant women }\end{array}$ \\
\hline $\begin{array}{l}\text { Article } 24^{(36)} \\
\text { 2015, Latin American } \\
\text { countries }\end{array}$ & $\begin{array}{l}\text { To analyze qualitatively reports of how and when health care providers pressed } \\
\text { women to sterilize. }\end{array}$ & $\begin{array}{l}\text { Qualitative study. } \\
\mathrm{P}=285 \text { women with HIV }\end{array}$ \\
\hline $\begin{array}{l}\text { Article } 25^{(37)} \\
\text { 2007, Brazil }\end{array}$ & $\begin{array}{l}\text { To describe the main reasons why HIV-positive women decide to be sterilized and } \\
\text { identify the factors associated with the choice of sterilization in HIV-positive women } \\
\text { in Ceará State, Northeast Brazil. }\end{array}$ & $\begin{array}{l}\text { Quantitative, cross-sectional study. } \\
\mathrm{P}=357 \text { women with HIV }\end{array}$ \\
\hline $\begin{array}{l}\text { Article } 26^{(38)} \\
\text { 2013, Malawi }\end{array}$ & $\begin{array}{l}\text { To analyze policies and guidelines on HIV and sexual and reproductive health in } \\
\text { Malawi for content on marriage and childbirth for HIV-positive couples. }\end{array}$ & $\begin{array}{l}\text { Qualitative study. } \\
P=20 \text { couples with HIV }\end{array}$ \\
\hline $\begin{array}{l}\text { Article } 27^{(39)} \\
2011, \text { Brazil }\end{array}$ & $\begin{array}{l}\text { To evaluate the perspective of professionals of university reproduction and public } \\
\text { assistance technology (ART) and HIV/AIDS services in Brazil, on the demand of } \\
\text { people living with HIV who wish to conceive. }\end{array}$ & $\begin{array}{l}\text { Qualitative, quantitative cross- } \\
\text { sectional case study. } P=\text { HIV service } \\
\text { professionals and managers. }\end{array}$ \\
\hline $\begin{array}{l}\text { Article } 28^{(40)} \\
2006, \text { Brazil }\end{array}$ & $\begin{array}{l}\text { To identify HIV-infected pregnant women in a referral center and investigate } \\
\text { infection and parity characteristics. }\end{array}$ & $\begin{array}{l}\text { Cross-sectional study. } \\
\mathrm{P}=85 \text { women with HIV }\end{array}$ \\
\hline $\begin{array}{l}\text { Article } 29^{(41)} \\
2013, \text { South Africa }\end{array}$ & $\begin{array}{l}\text { To compare the characteristics of teenager and adult mothers, including HIV } \\
\text { prevalence and VT rates. }\end{array}$ & $\begin{array}{l}\text { Quantitative study. } \\
P=19,093 \text { mothers with HIV }\end{array}$ \\
\hline $\begin{array}{l}\text { Article } 30^{(42)} \\
2002 \text {, Brazil }\end{array}$ & $\begin{array}{l}\text { To characterize and raise the nursing diagnoses of HIV-infected pregnant women in a } \\
\text { specialized prenatal service. }\end{array}$ & $\begin{array}{l}\text { Quantitative study. } \\
\mathrm{P}=25 \text { pregnant women with HIV }\end{array}$ \\
\hline
\end{tabular}




\section{RESULTS}

The characterization of the 30 articles analyzed is presented in Table 1.

The feelings of women living with HIV in relation to reproduction and motherhood, as well as the care provided and not made available by health professionals, are presented in Chart 2 .

Table 1 - Characterization of articles analyzed, LILACS/ PubMed/ BENF/ SCIELO, 2017

\begin{tabular}{lcc}
\hline & $\mathbf{n}$ & $\%$ \\
\hline Origin & & \\
Brazil & 20 & 68 \\
South Africa & 3 & 10 \\
East Africa (Malawi) & 2 & 7 \\
United Kingdom and Ireland & 1 & 3 \\
Thailand & 1 & 3 \\
Mexico & 1 & 3 \\
Argentina & 1 & 3 \\
Latin American countries (El Salvador, Honduras, Mexico and & 1 & 3 \\
Nicaragua) & & \\
Knowledge field & & \\
Nursing & 9 & 30 \\
Multiprofessional & 15 & 50 \\
Medicine & 4 & 13 \\
Psychology & 2 & 7 \\
Year of publication & & \\
2011-2016 & 17 & 57 \\
2006-2010 & 11 & 37 \\
2000-2005 & 2 & 7 \\
Research outlining & & \\
Experimental study & & \\
Quantitative cross-sectional & 1 & 3 \\
Qualitative & 9 & 30 \\
Qualitative and quantitative, cross-sectional study and case & 19 & 64 \\
study & 1 & 3 \\
Level of evidence & & \\
4 & & \\
6 & 1 & 3 \\
Total & 29 & 97 \\
\hline & 30 & 100 \\
\hline
\end{tabular}

Chart 2 - Description of the feelings of women living with HIV in relation to reproduction and motherhood, as well as the care provided and not made available by the health professionals evidenced in the studies analyzed, 2017

\begin{tabular}{|c|c|c|}
\hline Category & Aspects & Articles \\
\hline \multirow{3}{*}{$\begin{array}{l}\text { Feelings of women } \\
\text { living with HIV } \\
\text { regarding the } \\
\text { possibility of } \\
\text { motherhood and } \\
\text { in the course of a } \\
\text { pregnancy }\end{array}$} & $\begin{array}{l}\text { Motivation for reproduction: the desire to be mothers } \\
\text { versus the desire postponed or abolished after the } \\
\text { diagnosis of HIV infection }\end{array}$ & $(13-22,31)$ \\
\hline & $\begin{array}{l}\text { Fears and insecurities regarding the uncertainties } \\
\text { regarding the clinical outcomes of effective gestation }\end{array}$ & $(13-15,19-20,22-29)$ \\
\hline & $\begin{array}{l}\text { Effective gestation produces feelings of hope, renewal and } \\
\text { greater motivation for self-care }\end{array}$ & $(13,15,19-20,24-27,29-30)$ \\
\hline \multirow{4}{*}{$\begin{array}{l}\text { Care provided and } \\
\text { not provided by } \\
\text { health professionals } \\
\text { to women living } \\
\text { with HIV with regard } \\
\text { to reproductive } \\
\text { health as a right }\end{array}$} & $\begin{array}{l}\text { Support for reproductive decisions on safe means to effect } \\
\text { the desire for pregnancy in fact or during prenatal care }\end{array}$ & $(19,21,23,32-34)$ \\
\hline & $\begin{array}{l}\text { Disregard for the reproductive demands of women living } \\
\text { with HIV }\end{array}$ & $(14-15,19-21,24-28,31,34-41)$ \\
\hline & $\begin{array}{l}\text { Absence of reproductive planning in the follow-up of } \\
\text { women living with HIV }\end{array}$ & $(13-14,20,25,42)$ \\
\hline & $\begin{array}{l}\text { Presence of reproductive planning in the follow-up of } \\
\text { women living with HIV }\end{array}$ & $(15,19-20,22,25,34)$ \\
\hline
\end{tabular}

\section{Feelings of women living with HIV regarding the possibility of motherhood and in the course of a pregnancy}

From the total of 30 studies analyzed, 9 point out that women living with HIV express feelings involving the desire to be mothers that relate to a variety of reasons motivating reproduction ${ }^{(13-22,31)}$. However, some studies indicate that the desire ends up being postponed or abolished after the diagnosis of HIV infection (13-14,16,19,21-22).

A quantitative study with 148 women, carried out in São Paulo State, indicates that the majority are diagnosed with HIV when they are pregnant or when their children become ill(15). Knowing about seropositivity before or after becoming pregnant did not alter the motivation of wanting to generate a child ${ }^{(16)}$ because HIV did not affect life in general, which is exemplified by the formation of new marital partnerships after diagnosis and by the desire to start a family ${ }^{(13,15)}$.

Three qualitative Brazilian studies, which in total approached 46 women, point out the motivations to have children the partners' expectations, especially as a way to "reciprocate" their actions, and the belief that a child would be a complement to the conjugal relationship ${ }^{(16,20-21)}$. As well as the collection of one's own family or daughter/son in having one sister/brother, reiterating their own desire to live/revive the experience of motherhood and to expand/build a family ${ }^{(20-21,31)}$.

However, despite reporting such a desire, the fear of prejudice and the risk of infecting the child were explicit reasons for postponing the performance of motherhood plans ${ }^{(16)}$, even considering adoption ${ }^{(31)}$. Studies reveal that there are also those who have never had a desire to be a mother, or who have lost interest after discovering the diagnosis ${ }^{(13-14,16)}$. A qualitative study that addressed the effects of seropositivity on reproductive choices with 30 women in Brasilia city pointed out that among the reasons for the desire's cancellation are: fear of VT risk; seropositivity signified as a synonym for death and possibility of child orphanhood; fear of revealing the serological condition and/or exposing the partner to infection ${ }^{(16)}$.

On the basis of the studies analyzed, it is evident that the cancellation or maintenance of the desire to have children in relation to the diagnosis of seropositivity is variable and depends on the level of information and professional counseling to clarify the possibilities of a pregnancy in the context of HIV. To corroborate this, a quantitative study on the reproductive rights of 533 women and 206 men living with HIV in São Paulo, pointed out that the desire to have children showed to be associated with younger people (17 to 34 years) and with intermediate knowledge on prophylaxis for $\mathrm{VT}^{(17)}$.

A qualitative study with 7 women indicates that the coexistence with 
feelings of ambiguity between wanting or not to become pregnant was a conflict of a psychological nature that mobilized them, but no action for the prevention was carried out. This ambivalence can be aggravated by the lack of information and the difficulty of access to contraceptive methods, but also for reasons that are linked to sexuality and lust ${ }^{(18)}$.

Qualitative research with an HIV-positive woman, in Rio de Janeiro city, points out that the pain of frustration involving the belief that she cannot be a mother seems to be as great as the impact the illness has had on her life $\mathrm{e}^{(19)}$. On the other hand, in another study, the advent of Antiretroviral Therapy was the main argument to justify the viability of the decision to become pregnant and the overcoming of VT fear ${ }^{(20)}$. Thus, the deconstruction of the belief in not being a mother, the awareness that there is no 'no power', in fact, enables motherhood to emerge in its conception, and that of health professionals as a right of women living with HIV, as it should be objectively.

Qualitative studies in São Paulo and South Africa with men and women indicate that the desire to have children is not limited to an individual decision but is modeled by broader social norms ${ }^{(21-22)}$. The pressure of male partners is evidenced in the report of the partner's abandonment because, in their conceptions, it is not possible to have children ${ }^{(22)}$, an illustrative situation of social stereotypes that reinforce gender inequality in the power relations in which the woman should give in to the pressure and desires of the partner, disregarding their wills and health situation.

Thus, women living with HIV, whether those who carried out reproductive planning or those who did not even think about becoming pregnant, express different feelings, such as fears and insecurities in the face of uncertainties, whether they became aware of the pregnancy and/or during the period of gestation, indicated in the studies analyzed. When pregnancy occurs without having been planned and without having been the object of action in the course of health care, it becomes more complex to legitimize it. A qualitative study in São Paulo, based on the analysis of the oral history of a woman, points out that after the conformation process in relation to her condition, she had to seek the strength to continue living and dealing with the pregnancy. She had to face not only the fear related to the possibility of HIV VT but also to the risk of deformation of the baby due to the remedies ${ }^{(19)}$.

It is noticed that at the same time that there is the fear of the deformation of the baby there is also an incentive for the use of the drug, related to the issue of the reduction of the possibility of $\mathrm{VT}^{(19)}$. A qualitative study with 10 pregnant women in Rio de Janeiro showed that motherhood implies a greater commitment to own care compared to that of an uninfected woman. Coping and overcoming measures regarding possible HIV VT found their foundation of strength and motivation in adopting self-care measures ${ }^{(13,20)}$. Concern about the possibility of VT seems to contribute to a personal implication of women to "do everything that is right" from prenatal to postnatal(23). However, the exercise of child protection also emerged as an argument for refraining from gestation, considering the HIV infection as something malefic or that could bring life and suffering to the supposed baby ${ }^{(20)}$.

Besides $\mathrm{VT}^{(13,15)}$, women fear the acceleration of their disease progression and the possibility of dying, leaving their children alone $^{(14-15,24-25)}$. Add to this the fear of side effects of medication and of children suffering from prejudice and discrimination ${ }^{(15)}$, and concern that they cannot breastfeed ${ }^{(13)}$. Still, they feared they would not receive support from the people surrounding them, including their doctors, ratifying that the community's disapproval can also "shape", which could be considered as freedom of choice ${ }^{(22)}$.

A qualitative study in São Paulo State, with 15 women, points out that some justified the occurrence of a pregnancy as "an accident or carelessness", "it was my husband who wanted to", "every woman wants a child and I do not want to be different". These positions, according to the authors, characterize a subjective position of desensitization before their own desire, because they try to justify their acts in the attempt to be accepted by the other ${ }^{(26)}$. In this sense, another study pointed out that HIV infection did not substantially change the fact of wanting children ${ }^{(15)}$.

A qualitative research on the professional/patient relationship in Rio de Janeiro pointed out that because they do not have a child due to HIV, some women experience a sense of "incompleteness" when it comes to femininity, since they cannot guarantee a"healthy" child the feminine identity ${ }^{(27)}$. For some professionals, responsibility for caring for their children was seen as both the main motivation for self-care and the reason why they were not adequately addressed, and one case and another depended on the socio-familial support made available ${ }^{(27)}$.

A qualitative study in the northeast of Brazil with 36 relatives of children exposed to HIV pointed out that imagining themselves with an infected child gives rise to feelings, mainly of guilt for feeling responsible or unable to avoid this outcome. This is because pregnancy brings with it the constant memory of the diagnosis ${ }^{(28)}$. Some women, in a study in Thailand, stated that if the child had HIV it would be very difficult to deal with life in general ${ }^{(24)}$. This guilt for having generated a child at risk was also evidenced in a study in Ceará State, which sought to evaluate non-verbal communication in the interaction between mother and child. These were intimately attached to them, probably because of the desire to have them, thus defying the disease ${ }^{(29)}$. Having a child becomes a "teasing", the purpose of which is to generate a HIV seronegative offspring ${ }^{(26)}$.

Along with the work that shows feelings related to suffering, worries and displeasures, there have also been those who show that the news of motherhood can bring hope, renewal and motivation for the self-care of women living with HIV. Unplanned pregnancies become essential in their lives and are not only an encouragement not to develop a more advanced phase of the disease, but a reason to avoid the social misfortunes of infection and allow them to lead a meaningful life as a sign of hope, as opposed to the idea of death associated with $\operatorname{AIDS}^{(24,27,30)}$

Even in the face of a still strongly present stigma, two qualitative studies in Thailand and Mexico show that women do not "give up" of the dream of being a mother. Children acquire a vital meaning, often becoming the main, if not the only, reason in the fight against the feeling of hopelessness so frequent in this population $^{(24-25)}$. The possibility of these being born without the virus constitutes a source of motivation for their own lives ${ }^{(15,30)}$, makes them feel renewed ${ }^{(19)}$, brings satisfaction and brings them to a moment of happiness with expectations of generating a 
healthy child ${ }^{(13,20,30)}$. The act of generating a seronegative child gives them a brief sense of completeness, for thus fulfilling their "mission". However, even when the child is seronegative, there is the conflicting feeling that this does not negate the permanence of HIV in itself ${ }^{(26)}$, but try to believe in the possibility of cure, making this motivation to continue living ${ }^{(13,15,30)}$.

For HIV-positive mothers, in a study about the exercise of caring for their children in the first 6 months of life, the child represents the life that is early threatened by a disease without cure. Therefore, maternal care, through prophylaxis, intensifies as a way of "bargaining" longer life for itself (due to recent diagnosis), but also in relation to the negative of the child's viral load. Since maternal HIV would represent a first loss of dreams and projects; the child's infection would be a second loss, possibly more painful(29).

In a qualitative study that addressed the future perspectives of 10 pregnant women with HIV, they verbalized that living with HIV did not modify the concept of being a mother, on the contrary, motherhood would be a good experience in their lives, making it clear that the process experienced by when they become mothers, they resemble that of any HIV-seronegative woman ${ }^{(13)}$.

\section{Care provided and not provided by health professionals to women living with HIV with regard to reproductive health as a right}

Of the studies analyzed, 6 deal with support for reproductive decisions about safe means to effect the desire for the conception of a baby or, during the prenatal period, for an outcome that avoids $V T^{(19,21,23,32-34)}$. However, only one focuses on whether or not women have access to the least risky means of conceiving in serodifferent partnerships $^{(19)}$, the others focus on VT prevention ${ }^{(21,32-34)}$. As an example of support for reproductive decision, a qualitative study in São Paulo pointed out that for the interest of the HIV-positive woman, her doctor referred her to the Reproduction Center to perform treatment with the intention of becoming pregnant, ensuring her health and that of her child ${ }^{(19)}$.

A qualitative study in São Paulo State points out that, although health professionals advised patients about the risks of pregnancy in the context of HIV, they emphasized the importance of prophylactic measures of $\mathrm{VT}$, considering the possibility of pregnancy in this context ${ }^{(21)}$. After the information, the decision of the woman occurs in the attempt to counteract the possible damages of the seropositivity to its wider projects about the future. Integrating technical success, through VT prophylaxis, to life projects ${ }^{(10)}$ and reproduction, depends on dialogic interactions that allow an effective meeting between professionals and users, aiming at the most appropriate solution for each care situation ${ }^{(21)}$.

A study that aimed to evaluate reproductive health care and the integration of services for VT prevention in rural areas of Malawi found that there was an increase in the recruitment of women with HIV with at least one prenatal visit and in the performance of reproductive planning ${ }^{(32)}$. Corroborating, a quantitative study with 10,568 HIV-positive women in the United Kingdom and Ireland points out that demographic and clinical characteristics interfere in the probability of pregnancy repetition, and that these need to be considered in reproductive planning ${ }^{(33)}$.
A study in Argentina with 841 people with HIV and 89 coordinators of HIV/AIDS programs pointed out that women receive little information on contraceptive methods besides condoms. Only $7.1 \%$ of those who wanted a child had discussed their plans with a doctor, pointing out the need for reflection, since pre-conception planning is advisable in the context of $\mathrm{HIV}^{(34)}$. On the other hand, a qualitative study with 7 serodiffirent couples in Rio Grande do Sul States indicates the interest in participating in lectures, seeking information from professionals and the media related to the viability of pregnancy ${ }^{(23)}$.

However, the disregard for the reproductive demands of women living with HIV is still very much present in the practice of care. Given the occurrence of mostly unplanned pregnancies, the discussion about reproductive desire emerges, whether rights in this sphere are being guaranteed or not ${ }^{(28)}$, through access to reproductive planning, beyond the informational and prescriptive level, but from the point of view of care, from dialogical encounters, including longings and plans, and producing the means and the conditions for their fulfillment.

A qualitative study, with a patient in São Paulo State, points out the disregard or even the lack of knowledge of the professionals about the importance that should be attributed to the feelings and needs of women. The lack of this support, from the shelter of their anxieties, pains and afflictions, shows that work, especially Nursing, does not take place in a way that favors the quality of care ${ }^{(19)}$. It is evidenced that the assistance is mechanized and fragmented, transmitting technical information, not covering the aspects that permeate the Care, that is, an assistance that would not be sustained by the component of the integrality, covering beyond the clinical and biomedical aspects, the psychosocial dimension of the health-disease-care process, which includes thinking about the reproductive desire and the desire to constitute family configurations ${ }^{(19)}$.

The study pointed out that health professionals face a dilemma due to a general understanding that gestation in women with HIV is "itself" a "risk pregnancy" for both the mother and the baby, and for the partner who, in theory, is exposed to the infection, once the pregnancy is confirmed, it is made explicit the practice of unprotected sex ${ }^{(27)}$. A quantitative study in Porto Alegre with 77 HIV-positive pregnant women showed that the Brazilian strategies remain focused on the prevention of virus $\mathrm{VT}^{(21,35)}$. The risk of VT is used by health professionals both to discourage an intention to become pregnant and to guide the prophylaxis of $\mathrm{VT}^{(21)}$. However, these discourses did not contemplate considerations about the wills and motivations, indissociable from the care for their health, as from any other woman of reproductive age ${ }^{(21)}$.

According to two qualitative studies with HIV-positive women, in South Africa and in São Paulo, reproductive issues are not explicit in the health service space, both by users and professionals ${ }^{(14,21)}$. A study indicates that $70 \%$ affirmed that the theme of motherhood was never approached in its therapeutic followups $^{(20)}$. Silence appears as one of the most common practices for the prohibition of reproductive demands in health services, contributing to their not being explicitly explained by the users. Although it is expected that the health service is aware of the issue of prevention, it may inhibit initiatives that contravene such a prescription or lead to a "clandestine transgression" of medical 
counseling, contributing to the issue being addressed only after confirmation of pregnancy. The understanding is that health professionals view reproduction as a potential factor for the spread of HIV infection, and are therefore seen as something negative and blaming, thus showing little interest in asking questions or giving advice on sexual practices ${ }^{(34)}$. These epidemiological risk discourses are apprehended and reconstructed by women with HIV, according to each context ${ }^{(21)}$.

Although women are motivated to use contraception, the lack of discussion of their intentions is reflected in the inability to obtain sterilizations or other desired reproductive health services $^{(14)}$. This failure can be explained by the fragility of the therapeutic link and communication practices and, therefore, of the need to improve the care model in these aspects, valuing the feelings and the perception of the individuals in relation to their health condition to base their reproductive decisions ${ }^{(20)}$. This population thus relies on the media for any meaningful information regarding $\mathrm{HIV}$ and sexual and reproductive health ${ }^{(38)}$.

A qualitative study with 285 women with HIV in Latin American countries pointed out that health professionals, based on stigma and discrimination, annulled their reproductive rights, resulting in disinformation and denial of services to coerce women into accepting sterilization ${ }^{(36-37)}$ or counseling regarding abortion ${ }^{(25)}$. A study in Argentina states that unmet need for contraception is risky, as it may lead to discontinuation of unwanted pregnancies under unsafe conditions, resulting in increased risk due to immunological vulnerability $^{(34)}$. A study in Thailand ${ }^{(24)}$ points out that there is often a judgment on the part of health professionals about the non-use of contraception, and these women are oriented to "no longer have children"(34) by encouraging the condom. And when that advice is not followed, a study in Malawi points out that health professionals shout and still question them about their real health concerns, assuming that people with HIV should not get pregnant ${ }^{(38)}$.

Most of the professionals and managers interviewed in research on specialized HIV care services in 26 Brazilian state capitals ${ }^{(39)}$ stated that the counseling was focused mainly on the use of condoms and Antiretroviral Therapy and scarce counseling regarding reproductive planning or discussion about contraception ${ }^{(25,34,39)}$. In a study in Argentina, doctors categorically state that if other contraceptive options are offered, patients will stop using condoms, causing new infections or reinfections ${ }^{(34)}$. This paternalistic approach underestimates the ability of women to choose an appropriate contraceptive method.

Regarding reproductive desire, a study in Brazil ${ }^{(39)}$ points out that there is a lack of up-to-date information on the care of HIV-positive couples, the lack of scientific data regarding the risks of pregnancy in this context, and the lack of qualification of professionals to address such issues current, especially on interactions between antiretroviral drugs and hormonal and/ or intrauterine contraception, denoting lack of communication among specialists ${ }^{(34)}$.

The way women deal with the disease varies according to what the team presents as a possibility, leading to a pregnancy with or without adequate planning. The health team should be aware that when the HIV-positive woman becomes pregnant, she has expectations regarding pregnancy and her relationships with the health staff(26). On the other hand, a study shows that, even with all the structure and resources offered, such as multidisciplinary care, antiretroviral drugs and guidelines on contraception, they became pregnant again without planning ${ }^{(40)}$. A quantitative study of Minas Gerais State has demonstrated the need for qualitative research for a broader approach to issues involving motherhood in the context of HIV in order to contribute to the understanding and planning of the health process ${ }^{(40)}$ that guarantees the reproductive rights of this population.

Despite the high rates of prenatal care among pregnant teenagers in South Africa, the risk of VT is higher among teenager mothers infected with HIV compared to adults. Access to reproductive planning should be prioritized for this group in situations of greater vulnerability, from more accessible strategies $^{(41)}$. Likewise, it is pointed out the need for open spaces for seropositive young people to reflect on their demands and exchange experiences, denoting the importance of a continuing process of sex education ${ }^{(31)}$.

A study with 148 women in São Paulo pointed out that most would like to discuss sexuality issues with the professionals with whom they had more contact and created links. Even in services that are considered a reference for care of people with HIV, almost all of them have never talked about adherence to the use of condoms/contraceptives or any other aspect of reproductive health, at least not with the same emphasis as on adherence to antiretroviral agents. The study also points to the lack of guidelines on reproductive planning, the likelihood of HIV VT and even artificial insemination. Health professionals seem to be afraid that by opening the discussion, people will feel supported to take a stand on reproductive planning that these professionals often disagree with on their sometimes misguided technical conceptions and their own moral and ethical principles ${ }^{(15)}$.

A research has pointed out that among the reasons for not offering reproductive counseling in the specialized HIV care service is the lack of political decision making and human and financial resources, and the possibility of subsidizing antiretroviral agents for serodifferent couples was under discussion. In general, professionals recognized the difficulty in dealing with the desire to conceive and that the subject only arose during consultations due to the initiatives of the patient ${ }^{(39)}$. On the other hand, a study in Mexico points out that health professionals who advise how to reduce the risk of VT following prophylaxis protocols, examining regularly during pregnancy, are generally praised by the population served, being considered of excellent quality and "very human"(25).

The absence of reproductive planning in the follow-up of women living with HIV, that is, before pregnancy actually occurs, is a programmatic aspect, often resulting from the late search for health services (since pregnant), only when some signs are already evident, such as late period for several months. This suggests a possible lack of knowledge by these women about their body and sexuality, and their co-responsibility for the decision to generate a new being ${ }^{(20)}$. Study in Mexico points out that women report not receiving professional advice on reproductive planning ${ }^{(25)}$.

Unplanned pregnancies among HIV-positive women occurred in $88 \%$ of the cases in a quantitative study with 25 pregnant women infected with HIV in São Paulo; among these, $16 \%$ who reported not wanting the pregnancy knew their HIV seropositivity prior to 
the current gestation and expressed their intention to abort or refer the child for adoption ${ }^{(42)}$. In another study in South Africa, consideration was also given to abortion for not wanting to be pregnant or for fear that the child would be born incapacitated ${ }^{(14)}$. The decision whether or not to have an abortion can be influenced by psychosocial, cultural, economic, religious and ethical factors regardless of the HIV status ${ }^{(42)}$.

In view of the lack of reproductive planning, a study with 10 HIV-positive pregnant women in Rio de Janeiro, pointed out that they sometimes attribute "guilt" to the occurrence of pregnancy themselves, due to the "carelessness" of not adopting contraceptive methods or problems with the condom ${ }^{(13)}$. A study of 18 women in South Africa has shown that some feel ambivalent about discussing reproductive intentions with their partners because this would require discussions about their serological status to HIV and the use of contraceptives, and these revelations can result in negative consequences, such as abandonment of the partner ${ }^{(14)}$.

When reproductive planning occurs in the follow-up of women living with HIV, either as a personal reflection prior to gestation or as a programmatic action offered at the health service, the chances of more informed and secure decisions about the desire to be a mother increase. HIV seropositivity per se is not, or should not be, a limiting factor in the decision to become pregnant. According to a qualitative study with 8 HIV-positive women in Rio de Janeiro, although the fear of VT is present, it tends to be overcome by offering qualified and timely information regarding the desire and expectation of being able to generate a healthy child ${ }^{(20)}$. There is also reproductive planning through specific treatments, as pointed out by a woman who, through difficulty and fear of being a mother living with HIV, sought a Reproduction Center with the intention of becoming pregnant ${ }^{(19)}$. Study in Argentina points out that half of those who wanted to have a child were interested in having access to assisted fertilization techniques ${ }^{(34)}$.

Counseling that directs and discourages HIV-positive women from making genuine choices violates their rights to reproductive autonomy and control over their own bodies, and undermines confidence in the health professional ${ }^{(22)}$. They need to have their reproductive and sexual rights discussed and respected in all health services, in order to promote a supportive environment, providing conditions for knowing and making conscious choices ${ }^{(15)}$ in line with their wishes ${ }^{(25)}$ and sexual requirements and contraceptives in a more efficient and humane way ${ }^{(34)}$.

\section{Study limitations}

There is a limitation of the clipping established by the search strategy used, but consistent results were found in which they provide subsidies for the composition of a brief overview of the experience of motherhood in the context of HIV. Although the study concludes points that involve Nursing, it was not intended to exclusively evaluate the care performed by this professional.

\section{Contributions to the sectors of Nursing, Health or Public Policy}

It is hoped that this review may encourage reflection and debate among nurses and other health professionals in relation to motherhood in the context of HIV, in order to guarantee reproductive rights and to implement practices that incorporate a greater appreciation of the psychosocial dimension of life, because in the settings of which the processes of health, illness and self-care are produced. Another contribution is about the invisibility of the teenagers in the research on the subject, verified by the prevalence of studies with the adult population. It is also observed that there is a particular gap with regard to the knowledge of the specificities of those who were born infected by the virus, which becomes relevant, since they experience social experience from birth, and may be overlapping vulnerabilities.

\section{CONCLUSION}

This study has reviewed the scientific literature on the feelings of women living with HIV regarding motherhood and the professionals' practices and conceptions regarding the reproduction of these women, seeking to understand the extent to which more or less promising scenarios about the care provided with regard to reproductive health and rights.

Among the evidenced feelings are those expressive of the motivation for motherhood as desired experience, in which it acquires the meaning of hope and longing for a cycle of renewal, or reaffirmation, of life. At the same time, women experience fears and uncertainties, especially involving the risk of partner infection, VT, and possible child orphanhood. As care provided or not available, studies, to a lesser extent, indicate that there are professionals and services mobilized offering support to reproductive decisions. However, there is a predominance of studies that highlight the neglect and lack of provision of reproductive planning in the follow-up of women with HIV, together with an incipient care to the ambivalent emotional experiences of those who become pregnant (hope, insecurity, fear) of VT control, configuring violations, or at least negligence, to their reproductive rights, and of their partners.

It is concluded that there is still a long way to go in the process of structuring an integral and humanized care regarding the reception of the reproductive desire and the offer of alternatives for its viability - for the expansion of dialogue, access to reproductive technologies and strong psychosocial attention, aiming at guaranteeing reproductive rights. Nursing, an essential member of the health team needs to draw on conceptual foundations to expand its potential to implement innovative practices that do not detract from the technical successes and good clinical outcomes, but to bring them back into synergy with the desires, desires and experiences of people. This would be the "true measure" of the practical success of the treatments and achieving it depends on the alliance between self-care, hard work and involvement of professionals and health and social policies in the implementation of human rights.

\section{FUNDING}

This study was financed in part by the Coordenação de Aperfeiçoamento de Pessoal de Nível Superior - Brasil (CAPES) - Finance Code 001. 


\section{REFERENCES}

1. Ministério da Saúde (BR). Departamento de DST, AIDS e Hepatites Virais. Boletim Epidemiológico AIDS/DST. Ano IV. Brasília (DF): [Internet] 2015.95p. Available from: http://www.aids.gov.br/sites/default/files/anexos/publicacao/2015/58534/boletim_aids_11_2015_web_ pdf_19105.pdf

2. Cunha GH, Galvão MTG. Contraceptive and prevention methods of transmission/reinfection of the virus among patients with HIV/aids. Rev Rene [Internet]. 2011 [cited 2017 Dec 12];12(4):699-708. Available from: http://www.revistarene.ufc.br/vol12n4_html_site/a06v12n4.html

3. Engender Health/UNFPA. Saúde sexual e saúde reprodutiva das mulheres adultas, adolescentes e jovens vivendo com HIV e aids: subsídios para gestores, profissionais de saúde e ativistas/organização. Nova York: EngenderHealth e Brasília (DF): Unfpa, 2008. [Internet] Available from: http://www.unfpa.org.br/Arquivos/saude.pdf

4. Vargas EP, Maksud I, Moás LC, Britto R. HIV/AIDS, reproductive rights and reproductive technologies: mapping different perspectives. RECIIS [Internet]. 2010 [cited 2017 Dec 12];4(5):3-13. Available from: https://www.reciis.icict.fiocruz.br/index.php/reciis/article/view/482/pdf_225

5. Moreira-Silva R. Um corpo que abriga uma vida e um vírus: o significado da maternidade para mães soropositivas para HIV. [Dissertação]. Instituto de Psicologia, Universidade Federal da Bahia, Salvador/BA. 2012.

6. Ministério da Saúde (BR). Secretaria de Vigilância em Saúde. Programa Nacional de DST/AIDS. Recomendações para Profilaxia da Transmissão Vertical do HIV e Terapia Antirretroviral em Gestantes: manual de bolso. Brasília (DF). 2010. 172 p. Available from: http://www. aids.gov.br/pt-br/pub/2010/recomendacoes-para-profilaxia-da-transmissao-vertical-do-hiv-e-terapia-antirretroviral-em

7. Furtado Jorge HM, Hipólito MCV, Masson VA, da Silva RM. Prenatal care and public policies for women's health: integrative review. RBPS [Internet]. 2015 [cited 2017 Dec 18];28(1):140-8. Available from: http://periodicos.unifor.br/RBPS/article/view/2864/pdf_1

8. Cooper HM. Scientific guidelines for conducting integrative research reviews. Review of Educational Research.1982;52(2):291-302.

9. Galvão CM. Evidence Hierarchies. Acta Paul Enferm[Internet]. 2006[cited 2017 Dec 18];19(2):V. Available from: http://www.scielo.br/pdf/ape/ v19n2/en_a01v19n2.pdf

10. Ayres JR, Paiva V, Buchalla CM. Direitos humanos e vulnerabilidade na prevenção e promoção da saúde: uma introdução. In: Paiva V, Ayres JR, Buchalla CM (Orgs). Vulnerabilidade e Direitos Humanos. Prevenção e promoção da saúde: da doença à cidadania. Livro I. (pp. 9-22). Curitiba, PR: Juruá Editora. 2012.

11. Paiva, V. Dimensão Psicossocial do Cuidado. In: Paiva V, Ayres JR, Buchalla CM (Orgs). Vulnerabilidade e Direitos Humanos. Prevenção e Promoção da Saúde: da doença à cidadania. Livro II (pp. 41-72). Curitiba, PR: Juruá Editora. 2012.

12. Bellenzani R, Nemes MIB. Evaluation of a psychosocial intervention in caring for adherence to treatment for HIV/AIDS: a case study. Temas Psicol [Internet]. 2013 [cited 2017 Dec 12];21(3):765-89. Available from: http://pepsic.bvsalud.org/pdf/tp/v21n3/en_v21n3a08.pdf

13. Spindola T, Dantas KTB, Cadavez NFV, Fonte VRF, Oliveira DC. Maternity perception by pregnant women living with HIV. Invest Educ Enferm [Internet]. 2015 [cited 2017 Dec 12];33(3): 440-8. Available from: http://www.scielo.org.co/pdf/iee/v33n3/v33n3a07.pdf

14. Marlow HM, Maman S, Groves AK, Moodley D. Fertility intent and contraceptive decision-making among HIV positive and negative antenatal clinic attendees in Durban, South Africa. Health Care Women Int [Internet]. 2012 [cited 2017 Dec 12];33(4):342-58. Available from: https://www.ncbi.nlm.nih.gov/pmc/articles/PMC4083738/pdf/nihms593819.pdf

15. Santos NJS, Buchalla CM, Fillipe EV, Bugamelli L, Garcia S, Paiva V. Reproduction and sexuality in HIV-positive women, Brazil. Rev Saúde Pública [Internet]. 2002 [cited 2017 Dec 12];36(4 Suppl):12-23. http://www.scielo.br/pdf/rsp/v36n4s0/11159.pdf

16. Sant'Anna ACC, Seidl EMF. [Effects of seropositivity in reproductive choices of women living with HIV/Aids]. Psicol Reflex Crit [Internet]. 2009 [cited 2017 Dec 12]; 22(2): 244-51. Available from: http://www.scielo.br/pdf/prc/v22n2/a11v22n2.pdf Portuguese

17. Paiva V, Santos N, França-Junior I, Filipe E, Ayres JR, Segurado A. Desire to Have Children: gender and reproductive rights of men and women living with HIV: a challenge to health care in Brazil. AIDS Patient Care STDS [Internet]. 2007 [cited 2017 Dec 12];21(4):268-77. Available from: http://www.ip.usp.br/portal/images/stories/Nepaids/desire_to_have.pdf

18. Cechim PL, Perdomini FRI, Quaresma LM. [HIV positive pregnant women who do not follow the prenatal prophylaxis]. Rev Bras Enferm [Internet]. 2007 [cited 2017 Dec 10];60(5):519-23. Available from: http://www.scielo.br/pdf/reben/v60n5/v60n5a07.pdf portuguese

19. Camillo SO, Silva LO, Cortes JM, Maiorino FT. [The desire to be a mother facing HIV/AIDS infection]. Rev Enferm Cent O Min[Internet]. 2015[cited 2017 Dec 12];5(1):1439-56. Available from: http://www.seer.ufsj.edu.br/index.php/recom/article/view/552/834 Portuguese

20. Teixeira SVB, Silva GS, Silva CS, Moura MAV. Women living with HIV: the decision to become pregnant. Rev Pesqui: Cuid Fundam [Internet]. 2013[cited 2017 Dec 8];5(1):3159-67. Available from: http://www.seer.unirio.br/index.php/cuidadofundamental/article/view/1869/pdf_672

21. Silva NEK, Alvarenga AT, Ayres JRCM. AIDS and pregnancy: meanings of risk and challenges for care. Rev Saúde Pública [Internet]. 2006 [cited 2017 Dec 12];40(3):474-81. Available from: http://www.scielo.br/pdf/rsp/v40n3/en_16.pdf

22. London L, Orner PJ, Myer L. 'even if you're positive, you still have rights because you are a person': human rights and the reproductive choice of HIV-positive persons. Dev World Bioeth. 2008 Apr;8(1):11-22.

23. Langendorf TF, Padoin SMM, Paula CC, Souza IEO, Terra MG, Silva CB. Quotidian of being-a-couple: meanings of HIV vertical transmission prophylaxis and assessment possibilities. Esc Anna Nery [Internet]. 2015[cited 2017 Dec 12];19(2):259-64. Available from: http://www.scielo. 
br/pdf/ean/v19n2/en_1414-8145-ean-19-02-0259.pdf

24. Liamputtong P, Haritavorn N. My life as Mae Tid Chua mothers who contracted HIV disease: Motherhood and women living with HIV/AIDS in central Thailand. Midwifery [Internet]. 2014 [cited 2017 Dec 12];30(12):1166-72. Available from: http://www.midwiferyjournal.com/article/ S0266-6138(14)00100-4/pdf

25. Van Dijk MG, Wilson KS, Silva M, Contreras X, Fukuda HD, García SG. Health Care Experiences of HIV-Infected Women With Fertility Desires in Mexico: a qualitative study. J Assoc Nurses AIDS Care. 2014;25(3):224-32. doi: 10.1016/j.jana.2013.04.006

26. Zihlmann KF, Alvarenga AT. What is this desire? Reproductive decisions among women living with HIV/Aids from a psychoanalysis perspective. Saúde Soc [Internet]. 2015 [cited 2017 Dec 8];24(2):633-45. Available from: http://www.scielo.br/pdf/sausoc/v24n2/en_01041290-sausoc-24-02-00633.pdf

27. Aguiar JM, Simões-Barbosa RH. Relationship between health care professionals and HIV positive women: a gender approach. Cad Saúde Pública [Internet]. 2006 [cited 2017 Dec 12];22(10):2115-23. Available from: http://www.scielo.br/pdf/csp/v22n10/10.pdf

28. Alvarenga WA, Silva MR, Nascimento LC, Wernet M, Oliveira FFD, Dupas G. Experience of family members providing care for HIV-exposed children: beginning of the trajectory. Rev Gaúcha Enferm[Internet]. 2014[cited 2017 Dec 12];35(3):68-74. Available from: http://seer.ufrgs.br/ index.php/RevistaGauchadeEnfermagem/article/view/43938/31511

29. Paiva SS, Galvão MTG, Pagliuca LMF, Almeida PC. Non-Verbal Mother-Child Communication in conditions of Maternal HIV in an Experimental Environment. Rev Latino-Am Enfermagem [Internet]. 2010 [cited 2017 Dec 12];18(1):[08 telas]. Available from: https://www. revistas.usp.br/rlae/article/view/4117/4994

30. Vasconcelos SG, Galvão MTG, Aguiar MIF, Braga VAB. The perception of pregnant women dealing with HIV infection - an exploratory study Online Braz J Nurs [Internet]. 2006 [cited 2017 Dec 12];5(1):[6 páginas]. Available from: http://www.objnursing.uff.br/index.php/nursing/ article/view/61/19

31. Paiva V, Ayres JRCM, Segurado AC, Lacerda R, Silva NG, Silva MH, et al. The sexuality of HIV-positive Adolescents: rights and challenges for healthcare. Ciênc Saúde Coletiva [Internet]. 2011 [cited 2017 Dec 12];16(10):4199-210. Available from: http://www.scielo.br/pdf/csc/v16n10/a25v16n10.pdf

32. van den Akker TVA, Bemelmans M, Ford N, Jemu M, Diggle E, Scheffer S, Zulu I, Akesson A, Shea J. HIV care need not hamper maternity care: a descriptive analysis of integration of services in rural Malawi. BJOG [Internet]. 2012 [cited 2017 Dec 12];119:431-8. Available from: http:// onlinelibrary.wiley.com/doi/10.1111/j.1471-0528.2011.03229.x/epdf

33. French CE, Cortina-Borja M, Thorne C, Tookey PA. Incidence, patterns, and predictors of repeat pregnancies among HIV-infected women in the United Kingdom and Ireland, 1990-2009. J Acquir Immune Defic Syndr [Internet]. 2012 [cited 2017 Dec 18]; 59(3): 287-93. Available from: https://www.ncbi.nlm.nih.gov/pmc/articles/PMC3378493/pdf/ukmss-38020.pdf

34. Gogna ML, Pecheny MM, Ibarlucía I, Manzelli H, López SB. The reproductive needs and rights of people living with HIV in Argentina: Health service users' and providers' perspectives. Soc Sci Med. 2009 Sep;69(6):813-20.

35. Faria ER, Gonçalves TR, Carvalho FT, Lopes RCS, Piccinini CA. Coping Strategies Among Brazilian Pregnant Women Living With HIV. Paidéia [Internet]. 2014 [cited 2017 Dec 12];24(57):67-74. Available from: http://www.scielo.br/pdf/paideia/v24n57/0103-863X-paideia-24-57-0067.pdf

36. Kendall T, Albert C. Experiences of coercion to sterilize and forced sterilization among women living with HIV in Latin America. J Int AIDS Soc [Internet]. 2015 [cited 2017 Dec 8]; 18(1): 19462. Available from: https://www.ncbi.nlm.nih.gov/pmc/articles/PMC4374084/pdf/JIAS-18-19462.pdf

37. Oliveira F, et al. HIV-positive women in northeast Brazil: Tubal sterilization, medical recommendation and reproductive rights. AIDS Care[Internet]. 2007[cited 2017 Dec 8];19(10):1258-65. Available from: https://www.researchgate.net/ publication/5776367_HIV-positive_women_in_northeast_Brazil_Tubal_sterilization_medical_recommendation_and_reproductive_rights

38. Gombachika BC, Chirwa E, Malata A, Sundby J, Fjeld H. Reproductive decisions of couples living with HIV in Malawi: What can we learn for future policy and research studies? Malawi Med J [Internet]. 2013[cited 2017 Dec 12];25(3):65-71. Available from: https://www.ncbi.nlm.nih. gov/pmc/articles/PMC3859991/pdf/MMJ2503-0065.pdf

39. Rossi A, Amaral E, Makuch MY. Access of people living with HIV to infertility services: perspective of Brazilian healthcare professionals. AIDS Care. 2011;23(10):1329-35. doi: 10.1080/09540121.2011.564113

40. Romanelli RMC, et al. Profile of HIV-infected pregnant women at a reference prenatal care service in Belo Horizonte(MG). Rev Bras Saúde Matern Infant [Internet]. 2006 [cited 2017 Dec 12];6(3): 329-34. Available from: http://www.scielo.br/pdf/rbsmi/v6n3/31904.pdf

41. Horwood C, Butler LM, Haskins L, Phakathi S, Rollins N. HIV-infected adolescent mothers and their infants: low coverage of HIV services and high risk of HIV transmission in KwaZulu-Natal, South Africa. PLoS ONE[Internet]. 2013[cited 2017 Dec 12];8(9):e74568. Available from: http://journals.plos.org/plosone/article?id=10.1371/journal.pone.0074568

42. Vaz MJR, Barros SMO. Gestantes infectadas pelo HIV: caracterização e diagnósticos de enfermagem. Acta Paul Enferm[Internet]. 2002[cited 2017 Dec 8];15(2):7-17. Available from: https://www.researchgate.net/publication/ 277298197_Gestantes_infectadas_pelo_HIV_-_caracterizacao_dos_diagnosticos_de_enfermagem 